\title{
PERAN TEKNOLOGI FINANSIAL BAGI PEREKONOMIAN NEGARA BERKEMBANG
}

\author{
Abdul Hadi Ilman ${ }^{1}$, Muhammad Nurjihadi ${ }^{1}$, Gita Noviskandariani ${ }^{2}$ \\ ${ }^{1}$ Program Studi Ekonomi Pembangunan, ${ }^{2}$ Program Studi Manajemen, Fakultas Ekonomi dan Bisnis Universitas Teknologi Sumbawa \\ *)email: abdul.ilman@uts.ac.id
}

\begin{abstract}
:
The emergence of financial technology is rooted from developed countries with established infrastructure, sophisticated technology, and more digital society. While this is not the case for developing countries, fintech has found difficulties in penetrating developing countries and improving their financial inclusion. This research aims to find fintech best practices around the world and analyze how they could improve the economic life of people in developing countries. We divided into three main category of problems that fintech could contribute and give solution: lack of infrastructure, less digital society, and chaotic and informal society. Then we analyzed three fintechs represent the three categories: Flutterwave, Creditfix, and Malako. We found that these fintechs have been able to contribute to financial inclusion and economy because of these reasons: 1) the ability to find what people really need; 2) the ability to simplify the sophisticated and complex technology behind the simple product; and 3) the ability to collaborate with traditional financial service.
\end{abstract}

Keywords: Financial technology, financial inclusion

\section{Pendahuluan}

Perkembangan teknologi digital yang terjadi dalam beberapa dekade terakhir disebut-sebut sebagai Revolusi Industri 3.0 (ketiga). Sejak pertama kalinya terjadi revolusi industri pada abad ke-18 di Inggris, revulusi industri selalu menyebabkan perubahan tatanan industri yang mempengaruhi hampir setiap bidang, baik secara positif maupun negatif. Begitu juga dengan teknologi digital yang telah merubah secara radikal (disruptive), dimulai dengan teknologi informasi yang membuat arus informasi begitu cepat dan akses terhadap informasi pun menjadi sangat mudah. Namun, di sisi lain informasi kemudian menjadi aset yang paling penting dan bahkan menjadi komoditas yang sangat mahal. Informasi yang dimaksud adalah informasi dalam jumlah yang sangat besar (big data) dan jika dianalisis dengan baik dapat dimanfaatkan untuk tujuan tertentu secara efektif.

Dalam perspektif ekonomi, maka muncullah istilah ekonomi digital (digital economy) sebagai sebuah konsep aktivitas ekonomi yang bebasis pada teknologi digital. Ekonomi digital pertama kali dicetuskan oleh Tapscott (1994) yaitu tentang bagaimana teknologi dan strategi bisnis bertranformasi tidak hanya pada proses bisnisnya, akan tetapi juga transformasi cara produk dan jasa diproduksi dan dipasarkan, struktur dan tujuan perusahaan, serta dinamika kompetisi bisnis. Selain itu, ekonomi digital juga membawa kita pada episentrum komputer, telokomunikasi, dan hiburan. Sejauh ini ekonomi digital paling dapat dirasakan dengan adanya fenomena perdagangan secara elektronik (e-commerce) dan marketplace bagi jasa-jasa, seperti transportasi dan hotel.

Industri selanjutnya yang akan terdisrupsi adalah industri jasa keuangan, yang kemudian dikenal sebagai Teknologi Finansial/tekfin (Financial Technology). Terminologi tekfin mengacu pada perpaduan antara teknologi informasi dan jasa keuangan yang mampu merubah model bisnis dan kemudahan dalam memasuki industri. Menurut FSB cakupan Tekfin terdiri dari empat ketegori yaitu 1) deposit, lending, capital raising, 2) market provisioning, 3) payment, clearing, \& settlement, 4) investment \& risk management (Bank Indonesia, 2016).
Terminologi dan cakupan ini tidak membatasi tekfin pada batasan kelembangaan ataupun instrumen keuangan. Dengan demikian, secara pelaku tekfin dapat mencakup perbankan formal yang bersifat bank-driven, dan startup tekfin yang berbasis pada customer-driven.

Sayangnya, perkembangan tekfin sebagian besar masih terfokus pada negara maju dan sebagian negeri berkembang yang pada dasarnya sudah tersedia banyak pilihan dan akses terhadap produk dan jasa keuangan. Hal ini menjadi wajar karena infrastruktur pendukung bagi berkembangnya tekfin berada di negara maju, seperti akses internet misalnya. mereka pun juga memiliki tingkat literasi dan inklusi keuangan yang relatif tinggi dengan adanya lembaga keuangan yang mudah ditemui di berbagai tempat di negara maju. Sehingga pemanfaatan tekfin merupakan alternatif yang memberikan kemudahan dan efisiensi bagi masyarakat. Secara ekonomi, benefit marjinalnya (marginal benefit) tidaklah besar. Sementara itu, daerah dan negara yang minim infrastuktur jarang sekali mendapatkan perhatian. Sehingga jarak (gap) linterasi dan inklusi keuangan semakin jauh antara kota dan desa.

Perkembangan tekfin saat ini kebanyakan mensyaratkan tersedianya infrastruktur teknologi yang mutakhir untuk dapat mengoptimalkan manfaat dari inovasi produk dan jasa tekfin. Sistem pembayaran yang berbasis aplikasi di handphone misalnya, membutuhkan spesifikasi handphone yang lebih tinggi dan akses internet cepat. tekfin di bidang lending membutuhkan analisis risiko calon peminjam yang berlokasi di kota saja, karena akses yang lebih mudah bagi pengelola Tekfin. Sehingga bentuk inovasi semacam ini tidak akan mampu mendorong pertumbuhan ekonomi pada daerah yang tertinggal, daerah yang sejak awal tidak mempunyai infrastruktur yang memadai.

Sebagai sebuah inovasi, seharusnya tekfin dapat mengambil peran yang tidak dapat dipenuhi oleh industri perbankan dan lembaga keuangan formal lainnya. Produk dan jasa keuangan yang ditawarkan oleh penyedia tekfin seharusnya compatible dengan teknologi yang ada di negara-negara tertinggal, sehingga 
dapat menjadi subsitusi terhadap produk dan jasa keuangan yang ditawarkan oleh lembaga keuangan formal. Bukan sekadar meningkatkan kenyamanan dalam mengakses jasa keuangan seperti masyarakat di perkotaan, tekfin di daerah tertinggal dapat menjadi faktor utama pendorong pertumbuhan ekonomi masyarakat di daerah tersebut.

Hal ini kemudian menciptakan celah bagi penyedia jasa keuangan non-formal yang mudah ditemui oleh masyarakat menengah ke bawah. Dalam hal pinjam-meminjam biasanya bunga yang ditetapkan sangat tinggi. Dalam hal investasi produktif di sektor pertanian, dilakukan sistem bagi hasil yang seringkali memberatkan bagi petani. Dalam hal sistem pembayaran, masyarakat sangat mengandalkan pembayaran tunai karena tidak adanya atau sulitnya akses terhadap pembayaran non tunai, sehingga membatasi aktivtias perekonomian. Jika ini terus dibiarkan akan menyebabkan aktivitas ekonomi yang berbiaya tinggi dan akan memberikan disinsentif bagi masyarakat ekonomi menengah ke bawah untuk melakukan aktivitas produktif. Dan pada akhirnya aktivitas ekonomi yang tidak efisien ini tidak akan mampu mendorong ekonomi tumbuh dengan baik.

Perkembangan tekfin yang selama ini lahir dan berbasis negaranegara maju dan sudah mendekati potensi pasarnya bisa jadi tidak semuanya dapat dimanfaatkan di negara berkembang dan tertinggal. Akan tetapi, tekfin yang digadang-gadang disebut sebagai invoasi teknologi keuangan yang berbasis pada konsumen (cosumer based), justru harus dapat beradaptasi terhadap kondisi neara tersebut. Keberadaannya harus dapat menjangkau konsumen-konsumen yang tidak dijangkau oleh lembaga keuangan formal.

Dengan demikian, pertanyaan penelitian yang penting untuk dijawab: bagaimana praktik terbaik (best practice) yang pernah ada dalam bidang tekfin yang dapat mendorong perekonomian di negara-negara berkembang dan tertinggal? Negara berkembang dalam konteks global ini menjadi proksi bagi daerah tertinggal dalam konteks di Indonesia. Jika ditemukan secara empiris bawah tekfin mampu mendorong ekonomi negara berkembang secara signifikan, maka hal tersebut dapat menjadi rujukan bagi pemanfaatan tekfin di daerah tertinggal lainnya. Dalam konteks ini juga adalah bagaimana pemerintah dan bersama semua pihak dapat menciptakan ekosistem tekfin yang kondusif.

\section{Studi Literatur}

Penggunaan istilah tekfin secara sederhana merujuk kepada perpaduan antara teknologi dan pruduk keuangan keuangan, sehingga memberikan kemudahan bagi konsumen. Akan tetapi dalam praktiknya, istilah tekfin seringkali digunakan dalam dunia bisnis secara ambigu dan tidak konsisten. Ketiadaan definisi yang baku menyebabkan persepsi terhadap tekfin yang terlalu luas dan tanpa batas, atau bahkan sebaliknya terlalu sempit sehingga tidak dapat dipahami secara komprehensif.

Schueffel (2016) melakukan studi literatur terhadap 354 artikel ilmiah yang menyebutkan tentang tekfin untuk menemukan definisi Tekfin secara ilmiah. Dari sejumlah artikel tersebut, hanya ada 13 artikel ilmiah yang secara eksplisit memberikan definisi Tekfin. Dengan melakukan analisis semantik, Schueffel (2016) berkesimpulan bahwa definisi Tekfin adalah:

"Fintech is a new financial industry that applies technology to improve financial activities."

Definisi ini memberikan ruang lingkup yang cukup luas untuk ikut menyertakan teknologi yang telah meningkatkan jasa keuangan secara inkremental seperti APIs, teknologi perangkat mandiri (device independent technology), pemindai tanda (signature scanning) ataupun yang secara disruptive seperti Chat Bots, Block Chain, dan kecerdasan artifisial (artificial intelligence), dll. Namun di sisi lain, definisi ini secara jelas tidak memasukkan jasa keuangan yang berbasis kertas dan seringkali dilakukan secara tatap muka (Schueffel, 2016). Definisi ini juga mampu menjangkau segala bentuk inovasi keuangan jauh sebelum abad ke-21, selama menerapkan teknologi terhadap jasa keuangan dan mampu meningkatkan aktivitas keuangan.

Bagian terakhir dari definisi tersebut, "to improve financial activities", merupakan generalisasi terhadap berbagai definisi yang menyebutkan tujuan dari adanya Tekfin, yaitu antara lain untuk memfasilitasi aktivitas keuangan (Micu \& Micu, 2016), meningkatkan efisiensi jasa keuangan (Čižinská, et al (2016), Kim, et al (2016), Wharton Tekfin Club (2015)), serta memfasilitasi pembayaran, menyediakan infrastruktur, mengoperasikan lembaga keuangan (Langley, 2014).

Sementara ini Bank Indonesia (2016) mendeskripsikan Tekfin sebagai "fenomena perpaduan antara teknologi dengan fitur keuangan yang mengubah model bisnis dan melemahnya barreir to entry." Definisi ini mengidentifikasi dua implikasi utama dari perkembangan Tekfin, yaitu:

1. Berubahnya model bisnis, layanan keuangan dilakukan dengan konsep dan model yang berbeda dengan sebelumnya

2. Berkurangnya batasan untuk masuk (barrier to entry) ke dalam bisnis dengan munculnya pelaku dan penyedia jasa keuangan yang unregulated yang dapat menyediakan layanan keuangan sebagaimana yang dilakukan yang para pelaku yang regulated.

Teriminologi Tekfin dari Bank Indonesia ini tidak mengacu atau membatasi pada pengertian kelembagaan/institusional ataupun instrumen keuangan/pembayaran tertentu. Dengan demikian cakupannya menjadi sangat luas (beserta contohnya di Indonesia) dan bersifat non-exaustive (suatu model bisnis tekfin dapat masuk lebih dari satu kategori), dan dapat dilakukan oleh siapapun, baik itu lembaga keuangan formal ataupun perusahaan baru yang mengembankan model bisnis teknologi keuangan yang inovatif.

Berikut adalah kategori Tekfin (Bank Indonesia, 2016):

1. Deposit, Lending, Capital Raising

- Crowdfunding (mis: KitaBisa, CrowdTivate, WeCare.id, dll)

- Peer to peer lending (mis: Uangteman, Pinjam, Modalku, dll)

2. Market Provisioning

- E-Aggregators (mis: Cekaja.com, Cermati, Akunting Mudah, Compare88, dll)

\section{Payment, Clearing, \& Settlement}

- Mobile payment (P2P transfer) (mis: Samsung Pay, Apple pay, dll)

- Web-based payment (mis: Kudo, Dompetku, KasPay, dll) 
- $\quad$ Digital currency (mis: BitCoin)

4. Investment \& Risk Management

- $\quad$ Robo advice (mis: Stockbit.com)

- $\quad$-trading (mis: Bareksa.com)

- Insurance (mis: Rajapremi, Cekpremi, Asuransi88.com, dll)

\section{Sejarah dan Evolusi Financial Technology}

Mengacu pada definisi Tekfin sebelumnya, maka sejarah Tekfin dapat dilacak pada abat ke-19 dengan pertama kali ditemukannya telegraf. Sejak itu, industri keuangan terus mengalami evolusi yang merupakan hasil dari perkembangan teknologi yang ada saat itu. Tabel di bawah ini menunjukkan perkembangan Tekfin sejak abad ke-19 hingga saat ini.

Tabel 1. Sejarah Perkembangan Teknologi Finansial di Indonesia

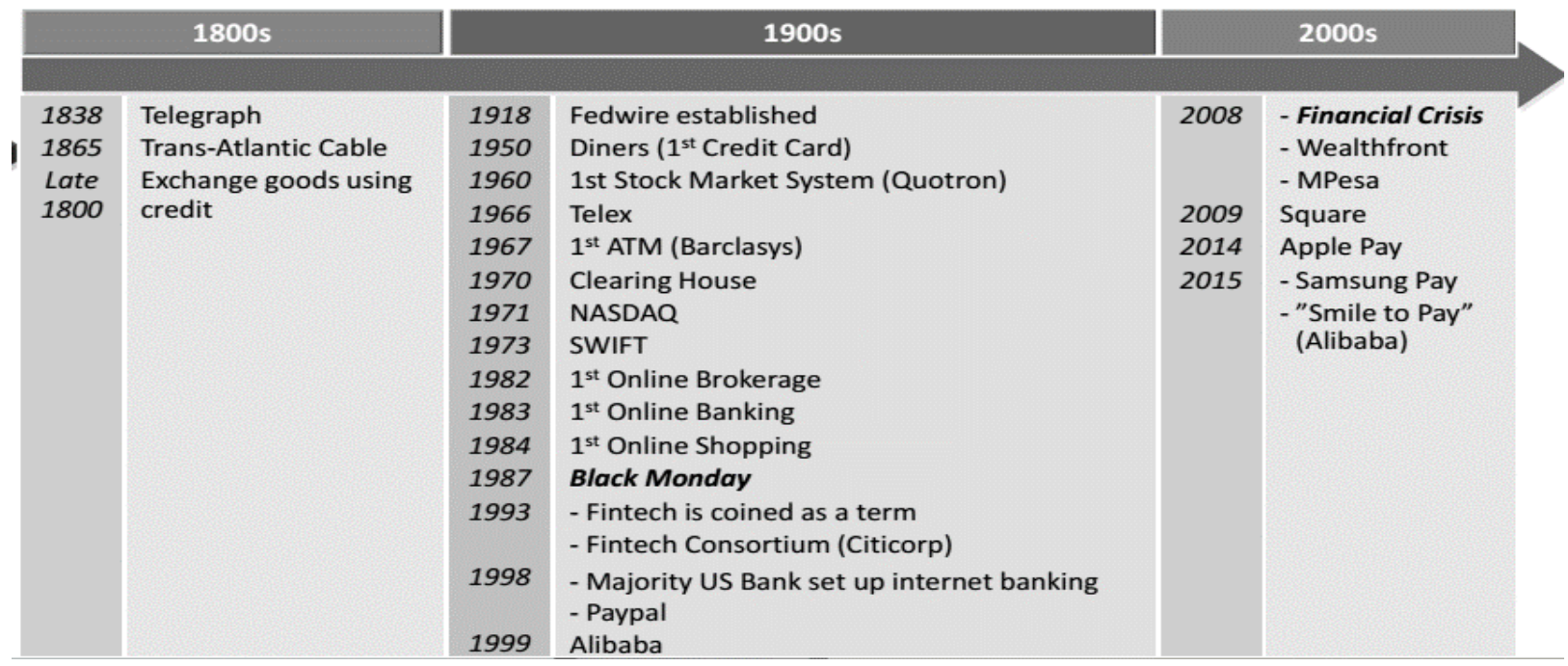

Sumber: Bank Indonesia

Berdasarkan tabel di atas, penggunaan istilah Tekfin pertama kali dilakukan pada tahun 1993 oleh Citigroup dengan nama resmi "Financial Service Technology Consortium, sebuah projek untuk memfasilitasi usaha kerjasama teknologi (Arner, et al., 2015). Dalam sumber lainnya disebutkan bahwa istilah Tekfin sudah ada sejak tahun 1972 yang dicetuskan oleh Manufacturers Hanover Trust (Bettinger, 1972). Dalam artikel disebutkan bahwa Tekfin merupakan akronim dari Financial Technology, “combining bank expertise with modern management science techniques and the computer."

Selama tiga dekade evolusi perkembangan Tekfin, dua dekade pertama merupakan periode dimana inovasi teknologi keuangan dimotori oleh bank (bank driven) dan lembaga keuangan formal lainnya. Inovasi seperti kartu kredit (1950), ATM (1967), online banking (1983), hingga Quotron pada sektor pasar modal (1960) adalah contoh-contoh inovasi yang digerakkan dan dilakukan oleh sektor keuangan formal. Pada sisi back end dan front end, pelaku industrinya mayoritas ada perbankan dan FMI (Financial Market Infrastructure provider). Karekteristik perkembangannya antara lain; ketatnya regulasi, dan tingginya investasi awal sehingga menyebabkan barrier to entry yang sangat besar.

Sementara itu, pada dekade terakhir yang dimulai sejak tahun 2000-an, inovasi teknologi keuangan bergeser ke arah yang lebih mengedepankan konsumen (customer driven). Kata kuncinya adalah inovasi yang melayani konsumen dengan berbagai kemudahan dan kenyamanan yang tidak dapat disediakan oleh lembaga keuangan formal. Pada sisi back end adalah munculnya crypto/digital currency, mata uang digital yang memberikan alternatif bagi konsumen selain mata uang yang diterbitkan oleh bank sentral. Sedangkan pada sisi front end, pelakunya tidak hanya berasal dari perbankan, akan tetapi semakin meluas baik yang berasal dari perusahaan besar non perbankan (dan non keuangan lainnya) atau berasal dari perusahaan yang baru (startup) didirikan dengan model bisnis yang inovatif. Misalnya Google yang mengembangkan Google Wallet sebagai alternatif sistem pembayaran, begitu juga dengan Samsung Pay dan Apple Pay. Ciri khusus pada periode ini adalah barrier to entry yang mudah yang disebebakan oleh dua hal: pertama, keuggulan kompetitif bagi pihak yang cepat dalam mengadopsi teknologi, dan kedua tidak optimalnya lembaga keuangan formal.

\section{Hubungan antara Financial Technology dan Pertumbuhan Ekonomi}

Secara konseptual, Tekfin yang merupakan akronim dari teknologi dan keuangan memiliki akar teori yang kuat dalam mendorong pertumbuhan ekonomi. Sistem keuangan memainkan peranan yang sangat penting dalam menyalurkan dana dari pihak yang kelebihan kepada pihak yang membutuhkan (Mishkin, et al., 2013), sehingga aktivtias perekonomian dapat berjalan dengan efektif dan efisien. Secara sederhana arus dana dalam sistem keuangan dapat digambarkan melalui gambar berikut ini: 


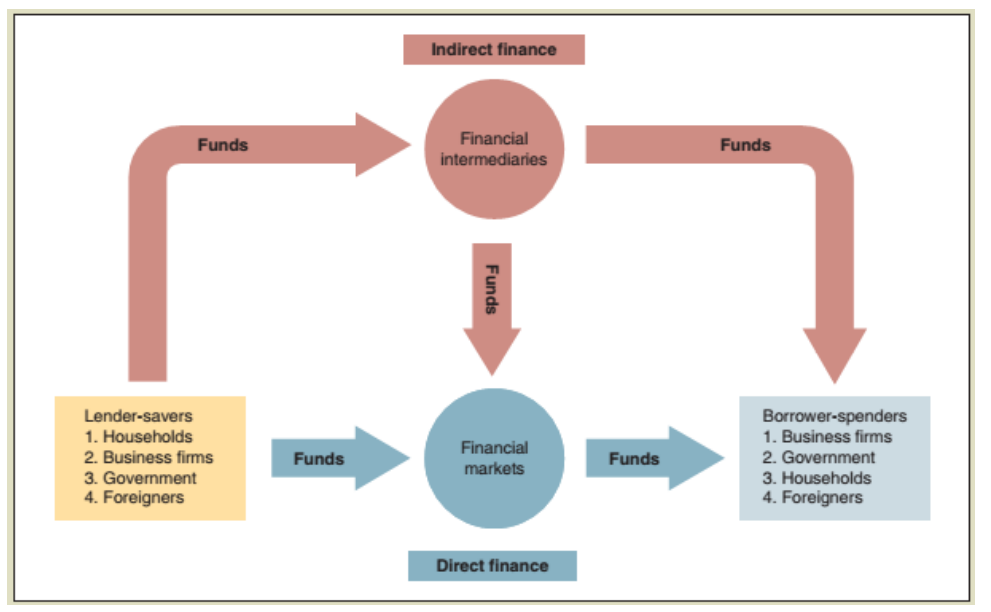

Gambar 1. Arus Dana dalam Sistem Keuangan

Sumber: Mishkin, 2013

Pasar keuangan dapat dilakukan melalui pembiyaan langsung (direct finance) maupun pembiayaan tidak langsung (indirect finance). Perbedaan mendasar dari kedua jenis ini adalah adanya lembaga intermediari keuangan pada pembiayan tidak langsung yang membentu proses tersalurnya dana. Peran lembaga intermediari keuangan sangatlah penting dalam proses arus dana ini, karena dapat mengurangi biaya transaksi, adanya sistem berbagi risiko, mencegah terjadinya adverse selection dan moral hazard dengan menyediakan informasi yang simetris. Dengan demikian, pemilik dan peminjam dana dalam jumlah kecil dapat berperan serta dalam pasar keuangan, sehingga secara keseluruhan dapat meningkatkan efisiensi dalam perekonomian (Mishkin, et al., 2013). Efisiensi yang dimaksud memungkinkan sumber daya yang terbatas dapat dialokasinya untuk aktivitas yang produktif dan mampu mendorong pertumbuhan ekonomi secara signfikan.

Sementara itu, teknologi dan inovasi dalam teori pertumbuhan ekonomi endogen dipandang sebagai satu-satunya faktor yang dapat mendorong pertumbuhan ekonomi dalam jangka panjang (Romer, 1994). Secara lebih spesifik teori ini memfokuskan pada eksternalitas positif dan dampat penyebaran (spillober effect) dari ekonomi yang berbasis pengetahuan (knowledge-based economy) yang menciptakan inovasi yang dapat mendorong pada pembangunan ekonomi.

Perpaduan unsur teknologi ke dalam sistem keuangan tentu secara teoretis memberikan dampak yang lebih besar terhadap perekonomian. Sistem keuangan yang formal saja telah mampu mengurangi adanya informasi yang tidak simetris antar pelaku keuangan, maka keberadaan teknologi (khususnya teknologi informasi) telah mendorong layanan keuangan pada level yang lebih tinggi lagi dan meningkatkan efisiensi layanan keuangan. Perkembangan teknologi informasi saat ini memungkinkan akses terhadap data yang tidak terbatas dan mendorong tercpitanya nilai tambah dari data yang sebelumnya belum pernah dioptimalkan. Melimpahnya data yang akurat dan bersifat real time akan mampu mengurangi potensi informasi asimetris secara lebih signfikan.

Solusi Tekfin memiliki potensi yang sangat besar bagi perkembangan usaha, terutama usaha mikor, kecil dan menengah (UKM). Tekfin dapat memberikan solusi yang efektif dan efisien bagi UMKM dengan menyediakan pilihan akses pembiayaan yang semakin mudah dan beragam (Australian Government, 2017).

\section{Metodologi Penelitian}

Penelitian ini menggunakan pendekatan kualitatif dengan tujuan untuk dapat memahami fenomena secara mendalam apa yang menjadi pertanyaan dalam penelitian ini dengan mengumpulkan data sedalam-dalamnya dari berbagai sumber yang dapat diakses. Dengan metode ini, peneliti melandaskan pada data yang ada kemudian memanfaatkan teori dan bukti empiris yang ada sebagai bahan penjelas, dan kemudian akhirnya dapat memberikan kesimpulan mengenai suatu fenomena.

Sementara itu, jenis penelitian ini adalah studi kasus yaitu dengan melakukan pengujian secara rinci terhadap satu latar atau satu subjek atau satu tempat penyimpanan dokumen atau satu peristiwa tertentu..

Dalam pengumpulan data, teknik yang digunakan dalam penelitian ini adalah Studi Pustaka, yaitu dengan mengumpulkan dan menganalisis artikel ilmliah yang terkait dengan Fintech. Secara lebih khusus, kajian pustaka ini bertujuan untuk mendapatkan informasi dan bukti empiris mengenai praktik terbaik dalam implementasi Fintech pada daerah dengan infrastruktur yang belum memadai.

Teknik analisis data yang digunakan dalam penelitian ini adalah:

1. Penyederhanaan data (data reduction)

Data-data yang diperoleh dari hasil studi pustaka, observasi, dan wawancara dirangkum dengan memilah halhal yang penting. Data yang disederhanakan akan memberikan gambaran yang lebih jelas dan mudah dalam proses penyajian data dan pengambilan kesimpulan.

2. Penyajian data (data display)

Proses penyusunan informasi yang kompleks dalam bentuk sistematis, sehingga menjadi bentuk yang sederhana serta dapat dipahami maknanya. Dalam penulisan kualitatif, penyajian data bisa dilakukan dengan bentuk uraian singkat, bagan, hubungan antar kategori dan sejenisnya, 
tetapi yang paling sering digunakan adalah teks yang bersifat naratif.

\section{Simpulan (conclusion drawing)}

Pengambilan kesimpulan dalam penelitian kualitatif bersifat induktif, yaitu diawali dengan narasi mengenai fenomena pada studi kasus yang telah disajikan dan kemudian dirumuskan menjadi konsep, model, atau teori yang bersifat umum.

\section{Hasil Dan Pembahasan}

Keberhasilan Tekfin dalam melakukan disrupsi dan berkontribusi bagi perekonomian negara maju belum tentu dapat melakukan hal yang sama di negara berkembang. Lahirnya tekfin sejak awal merupakan hasil inovasi akibat akumulasi pengetahuan dan ekosistem di negara maju, yang sulit ditemukan di negara maju. Oleh karena itu, mengetahui faktor apa saja yang membuat tekfin sukses secara umum (di negara maju) dapat membantu memahami kebutuhan inovasi tekfin bagi negara berkembang dan tidak sekadar replikasi sepenuhnya, namun mungkin bisa diikuti dengan modifikasi.

Drummer et al. (2016) melalui McKinsey melakukan analisis terhadap 1.500 perusahaan tekfin di dunia untuk mengetahui secara lebih mandalam mengenai keunggulan jasa dan model bisnis perusahaan tekfin tersebut. Secara khusus kesuksean perusahaan tekfin tersebut memiliki karakteristik:

1) Perusahaan tekfin ramping, lincah, dan inovatif. Dengan menggunakan teknologi yang paling mutakhir, keterampilan sumber daya manusia tinggi, dan sistem kerja yang dinamis, perusahaan tekfin mampu melakukan disruption di sektor jasa keuangan melalui pemenuhan ekspektasi konsumen menggunakan proses yang ramping dan lebih berorientasi kepada konsumen, serta mampu melakukan akselerasi kecepatan inovasi mereka.

2) Perusahaan tekfin fokus pada segmen individu dalam sebuah rantai nilai. Jasa pembayaran meruapakan fokus utama dari sebagian besar perusahaan tekfin di dunia, karena sangat menyentuh kebutuhan individu secara personal. Selain itu, jasa lainnya antara lain: investasi finansial, pinjaman, dan manajemen aset.

3) Perusahaan tekfin sejauh ini menargetkan pelanggan privat (dan bukan UMKM atau korporasi). Alasan utamanya adalah rendahnya barrier to entry dan keterampilan yang dibutuhkan untuk mendirikan perusahaan tekfin yang memberikan pelayanan pada konsumen privat. Selain itu, kepemilikan ponsel yang tinggi juga memberikan kontribusi terhadap perkembangan tekfin.

Sebagian besar aspek di atas merupakan karekteristik negara maju dan sedikit sekali ditemukan pada negara berkembang. Sementara di negara-negara berkembang pengembangan tekfin dihadapkan pada tiga masalah utama: keterbatasan infrastruktur (cloud service), pengguna yang bersifat "less digital" dibanding negara maju, dan pengguna yang kehidupan ekonominya tidak teratur dan berbasis sektor informal (Kendall, 2017). Dengan karakteristik seperti ini, tekfin dengan teknologi yang paling mutakhir belum tentu dapat diaplikasikan pada negara berkembang. Namun sebaliknya, dengan sumber daya manusia tekfin yang handal seharusnya dapat memberikan solusi aplikatif sesuai dengan karekteristik tersebut.

\section{Solusi bagi Keterbatasan Infrastruktur Cloud Service}

Fakta bahwa keterbatasan infrastruktur komputasi awan menciptakan kesempatan berkembangnya perusahaan tekfin yang berfokus pada penyediaan jasa insfrastruktur (infrastructure as a service, IaaS) dan regulation technology (regtech). IaaS merupakan salah satu jenis komputasi awan (cloud computing) selain software as a service (SaaS) dan platform as a service (PaaS).

Perbedaan ketiga jenis tersebut terletak pada ruang lingkup jasa yang ditawarkan masing-masing dan hak pengelolaannya. SaaS menawarkan jasa dan produk yang lengkap (mulai dari aplikasi, data, runtime, middleware, operating system, virtualisasi, server, penyimpan, dan jaringan) yang dikelola sepenuhnya oleh penyedia jasa, sementara komsumen hanya sebagai pengguna akhir. PaaS menawarkan jasa yang mirip dengan SaaS, namun tanpa jasa aplikasi dan data, dimana keduanya disediakan dan dikelola oleh pengguna akhir. Sementara Iaas menawarkan ruang lingkup jasa yang lebih sedikit dan menjadi blok bangunan (building block) dasar dalam sistem komputasi awan. Secara mendasar Iaas memberikan akses terhadap virtualisasi, server, penyimpanan data, dan jaringan (Tanmoy Ray, 2018).

Pemanfaatan komputasi awan memberikan banyak keuntungan bagi pengembangan jasa keuangan terutama di negara-negara berkembang, antara lain (Tanmoy Ray, 2018):

i) Hemat biaya (cost effective), dengan mengurangi kebutuhan belanja modal untuk membangun dan mengatur piranti keras dan piranti lunak di pusat data sendiri.

ii) Kemungkinan (feasibility), kemudahan dalam penggunaan data

iii) Keandalan (reliability), dengan sistem keamanan yang tinggi menjadikan data selalu terlindungi dan dapat diakses melalui berbagai cara dengan mudah.

iv) Produktivitas (productiviy) meningkat, karena semakin efisien dalam penyimpanan dan penggunaan data.

Penggunaan komputasi awan pada sektor keuangan terutama mencakup gerbang pembayaran (payment gateway), dompet digital (digital wallet), transfer dana online, pembayaran online yang aman. Contoh perusahaan tekfin yang menggunakan Iaas sebagai layanan utamanya di negara berkembang adalah Flutterwave dan Trulioo. Pada bagian selanjutnya akan dibahas secara khusus mengenai Flutterwave untuk mengetahui bagaimana IaaS dibangun dan dapat memberikan solusi bagi negara-negara berkembang.

\section{Flutterwave}

Flutterwave merupakan perusahaan tekfin berbasis di Afrika yang menyediakan infrastruktur sistem pembayaran digital modern yang mampu mengintegrasikan semua jenis, jaringan, dan metode pembayaran (web, mobile, ATM, point of sales $(P O S)$ ) di negaranegara Afrika, serta terkoneksi secara langsung dengan sistem pembayaran global.

Setidaknya terdapat 2 latar belakang dan masalah utama yang melandasi model bisnis Flutterwave:

1. Ekosistem dan infrastruktur sistem pembayaran di Afrika masih terfragmentasi. Ada sistem pembayaran berbasis kartu, mobile money, dan lainnya, akan tetapi masingmasing membangun infrastrukturnya sendiri. Sehingga jika sebuah merchant bermaksud untuk bisa menerima pembayaran semua metode, maka dia harus 
mengintegrasikan semua jenis pembayaran tersebut secara mandiri. Selain mahal, sistem pembayaran lintas jaringan dan metode juga membutuhkan waktu yang lama, bahkan tidak jarang berakhir pada gagal transaksi.

2. Sistem pembayaran yang diadopsi dari luar dibangun berbasis kartu (debit dan kredit), karena beranggapan bahwa sistem berbasis kartu yang sudah berhasil di negaranegara maju juga akan berhasil di Afrika. Pada kenyataannya, secara keseluruhan hanya sekitar 3\% populasi Afrika yang memiliki kartu kredit dan hanya $23 \%$ yang memiliki akun pada lembaga keuangan formal (Triki and Faye, 2013). Memaksakan sistem pembayaran berbasis kredit sejauh ini tidak berhasil meningkatkan inklusi keuangan penduduk Afrika. Sementara itu metode pembayaran yang populer digunakan oleh penduduk Afrika adalah mobile money, dimana di Kenya sekitar 68\% penduduk menggunakan mobile money dan di negaranegara Afrika penggunanya terus meningkat karena kemudahan dalam penggunaannya. Pertumbuhaan penggunaan mobile money di Afrika yang berbasis teknologi rendah tidak sejalan dengan perkembangan teknologi finansial di negara-negara maju yang lebih mengandalkan teknologi mutakhir, sehingga hal ini dapat menyebabkan pengguna mobile money semakin terabaikan dalam sistem pembayaran global.

Latar belakang ini menjadikan sistem pembayaran di Afrika menjadi rumit, tidak efisien, dan berbiaya mahal. Sebagai contoh, seseorang yang ingin melakukan transfer dana ke sebuah negara di Afrika membutuhkan waktu setidaknya satu minggu hingga dana tersebut berada di rekening perbankan lokal dengan mata uang lokal negara tersebut. Pembayaran antar jenis dan metode di dalam negara-negara Afrika pun cukup sulit: transfer dana dari rekening ke mobile money dan sebaliknya, kartu kredit ke mobile money dan sebaliknya, serta berbagai jenis pembayaran antar metode. Selain itu, terfragmentasinya sistem pembayaran dan seringnya kejadian gagal transaksi menyebabkan merchant tidak lagi mau repot dengan POS dan lebih menyukai menerima pembayaran secara tunai. Akibat lebih besarnya lagi akan mendorong masyarakat yang lebih bergantung pada tunai.

Flutterwave yang didirikan pada tahun 2016 merupakan API (application programming interface) yang memungkinkan proses transaksi pembayaran lintas jaringan, metode dan platform, bahkan lintas mata uang di negara-negara Afrika (Y Combinator, 2016). Dengan Flutterwave setiap pengguna dapat melakukan dan menerima pembayaran dari berbagai jenis kartu, mobile money, rekening bank, ke dan dari seluruh Afrika bahkan dunia dengan sangat cepat dan mudah. Hal ini memungkinkan penduduk Afrika tetap menggunakan mobile money mereka dan penyedia jasa global juga tetap menggunakan sistem pembayaran mereka sendiri (seperti kartu kredit dsb), namun dapat melakukan transaksi keuangan dengan mudah. Sehingga Flutterwave menyelesaikan masalah fragmentasi sistem pembayaran di Afrika sekaligus menghubungkan penduduk Afrika pada sistem pembayaran global.

Secara sederhana dapat dikatakan bahwa seorang pekerja informal di Afrika yang tidak memiliki rekening bank dan kartu kredit, tetapi hanya mempunyai mobile money, dapat melakukan transaksi keuangan dari dan ke seluruh dunia dengan mudah, tidak peduli jenis dan metode pembayaran yang digunakan oleh counterpart-nya. Begitu juga sebaliknya, sebuah perusahaan global yang mempekerjakan sumber daya manusia di beberapa negara di Afrika dapat dengan mudah membayar gaji dan upahnya melalui Flutterwave tanpa harus pergi ke masing-masing bank untuk transfer dan menukarkannya ke dalam mata uang lokal negara tersebut.

Model bisnis yang ditawarkan Flutterwave sangat solutif dan berpotensi meningkatkan perekonomian negara-negara Afrika, sehingga sampai tahun 2018 perusahaan telah mendapatkan pendanaan mencapai $\$ 10,1$ juta dari beberapa investor dan modal vetura antara lain: Green Visor Capital, Y Combinator, Google Launchpad Accelerator, dan Greycroft (Crunchbase, 2018).

Hingga Agustus 2018, nilai transaksi yang menggunakan Flutterwave telah mencapai 10 juta transaksi dengan nilai $\$ 1,2$ miliar (Flutterwave, 2018). Ini menunjukkan bahwa solusi Flutterwave benar-benar menyentuh pada akar permasalahan yang terjadi pada sistem pembayaran di Afrika. Dengan demikian, penduduk Afrika dapat dengan mudah, murah, cepat, dan aman melakukan transaksi keuangan dan ekonomi lainnya, sehingga perekonomian dapat tumbuh.

\section{Solusi bagi Masyarakat yang Less Digital}

Gaya hidup digital secara sederhana diartikan sebagai kehidupan yang berbasis internet, baik dalam hal pekerjaan, hiburan, sosial, pendidikan, keuangan, dan sebagainya. Penetrasi gaya hidup digital didukung oleh tingginya kepemilikan smartphone dan berkembangnya teknologi informasi. Gaya hidup digital menciptakan jejak digital (digital footprint) yang merekam semua aktivitas individu selama menggunakan internet, seperti halaman web apa saja yang pernah dikunjungi, surat elektronik yang diterima dan dikirim, data personal dan komentar di media online, barang yang pernah dibeli, serta informasi personal lainnya. Jejak digital ini membentuk profil individu berdasarkan aktivitasnya dalam menggunakan internet. Profil ini kemudian secara aggregat maupun spesifik digunakan untuk menganalisis perilaku dan potensi risiko individu tersebut. Perusahaan tekfin sangat mengandalkan data jejak digital seseorang untuk dapat memberikan peniliaian dan penawaran yang khusus bagi invididu tersebut. Itulah mengapa tekfin dapat menjadi solusi bagi masyarakat di negara berkembang dengan gaya hidup digital yang tinggi.

Sementara itu, penduduk negara berkembang diindentikkan dengan kehidupan yang tidak terlalu bersentuhan dengan dunia digital, walaupun tentu saja sebagian kecil diantara mereka sangat familiar dengan gaya hidup digital. Berdasarkan data International Telecommunication Union, pada akhir 2017 terdapat 53,6\% rumah tangga dunia yang memiliki akses terhadap internet. Namun untuk negara berkembang angkanya hanya 42,9\% dan untuk negara tertinggal (Least Developed Country) lebih rendah lagi hanya $14,7 \%$. Benua Afrika merupakan benua dengan persentase populasi yang mempunyai akses internet terendah di dunia, yaitu $18 \%$, kemudian diikuti oleh negara Arab 47,2\% dan Asia Pasifik 48,1\% (International Telecommunication Union, 2018).

Keterbatasan akses terhadap internet berarti keterbatasan atau ketiadaan jejak digital. Dampaknya adalah sedikit sekali atau bahkan tidak ada satupun data yang bisa membentuk profil digital seseorang untuk dianalisis oleh algoritma canggih milik perusahaan tekfin. Sehingga mereka tidak dapat menggunakan produk dan jasa tekfin. Misalnya, jika perusahaan tekfin bergerak di bidang pemberian kredit, maka artinya penduduk yang less digital tidak dapat menikmati kredit tersebut dengan mudah. Selain itu, masyarakat seperti ini biasanya juga tidak memiliki akses terhadap jasa keuangan formal seperti perbankan. Sehingga 
sumber terakhir bagi mereka untuk mendapatkan kredit adalah jasa keuangan informal dengan biaya yang jauh lebih mahal.

Salah satu contoh perusahaan tekfin yang dapat memberikan solusi bagi masyarakat yang less digital adalah Creditfix, sebuah perusahaan yang berasal dari Pakistan. Creditfix menyediakan platform untuk membangun profil kelayakan kredit seorang individu yang belum atau baru punya akses terhadap lembaga keuangan formal berdasarkan data alternatif. Dengan demikian, individu tersebut bisa mendapatkan kredit formal yang adil dan transparan, dan lembaga keuangan dapat memberikan kredit secara efisien dan berkelanjutan.

Sebagai sebuah platform, Creditfix berperan dalam menghubungkan industri keuangan formal untuk mengakses nasabah yang sebelumnya tidak tersentuh, dengan nasabah informal yang tidak mempunyai data formal untuk bisa mengakses jasa keuangan formal. Industri keuangan formal akan sangat diuntungkan karena tidak perlu membangun sistem dan infrastruktur untuk melakukan profiling calon nasabah yang sebelumnya tidak bankable. Calon nasabah juga diuntungkan karena dengan dibuatnya profil secara mudah berarti dapat dengan mudah mengkases produk keuangan.

Profil nasabah dibangun menggunakan big data yang diperoleh dari perilaku keseharian nasabah tersebut diantaranya: histori pekerjaan, catatan belanja pulsa, pembayaran tagihan utilitas (listrik, air, dsb), histori panggilan dan SMS, informasi perjalanan, dan penggunaan media sosial. Data-data ini kemudian diolah dengan machine learning dan dilakukan predictive modelling. Hasil dari pengolahan data ini adalah skor kelayakan kredit seseorang. Sehingga dengan mudah menjadi acuan apakah seseorang layak mendapatkan kredit dari jasa keuangn formal.

Kelebihan menggunakan data-data tersebut dibandingkan data formal yang biasa diisi oleh calon nasabah saat melakukan aplikasi kredit secara formal di lembaga keuangan adalah data ini lebih mencerminkan perilaku keuangan seseorang dan bersifat dinamis. Sehingga penyedia kredit dapat setiap waktu dapat meninjau skor kredit seorang nasabah secara real time dan melakukan tindakan preventif yang tepat untuk mencegah terjadinya kegagalan membayar dan melunasi kredit.

Dengan basis data ini, masyarakat yang less digital dapat mengakses jasa keuangan formal secara adil dan transparan sesuai dengan profilnya, dan terhindar dari jasa keuangan informal yang seringkali menerapkan biaya yang tinggi dan meningkatkan risiko gagal bayar.

\section{Solusi bagi Masyarakat yang Kehidupan Ekonominya tidak Teratur}

Salah satu ciri utama dari kehidupan masyarakat di negara-negara berkembang dengan pendapatan yang rendah adalah kehidupan ekonomi yang tidak teratur. Ketidakteraturan tercermin antara lain melalui tidak adanya tabungan untuk dana darurat, atau tabungan untuk dana pendidikan anak di masa yang akan datang. Mereka menjalani kehidupan ekonomi sehari-hari tanpa perencanaan yang baik. Pendapatan hari ini bisa jadi habis untuk hari ini saja, bahkan jika kurang harus menjual barang-barang yang bisa dijual. Mereka juga seringkali harus berusaha keras untuk bisa membiayai kebutuhan mendesak dan darurat karena tidak adanya tabungan. Hal ini terkonfirmasi melalui studi lapangan yang kami lakukan di daerah Sumbawa.

Pendapatan yang rendah dan tidak adanya perencanaan keuangan yang baik menjadikan mereka sangat rentan terhadap kejadian- kejadian tidak terduga yang membutuhkan sumber daya finansial yang besar. Ditambah juga keterbatasan akses terhadap jasa keuanga formal, maka akan semakin susah bagi mereka untuk bisa bertahan dalam kondisi kesulitan ekonomi seperti itu. Yang terjadi selanjutnya adalah mereka akan terjebak pada jasa keuangan informal dengan bunga tinggi dan akan semakin tinggi sering waktu karena ketidakmampuan untuk melunasi pada jatuh temponya.

Malako, sebuah perusahaan start up yang berasal dari Uganda memberikan solusi bagi permasalahan ini dengan cara memberikan kredit mikro yang fleksibel dan terjangkau bagi konsumen berpenghasilan rendah. Semua proses dari aplikasi, pencairan, hingga pelunasan dilakukan melalui ponsel (Nicole Jao, 2017).

Kredit yang terjangkau artinya tingkat pengembalian atau bunga yang rendah. Sementara fleksibel berarti nasabah dapat mengembalikan pinjaman saat mereka sudah mempunyai uang atau cukup membayar cicilan minimun saat mereka tidak mempunyai cukup dana.

Pendiri Malako memiliki cita-cita untuk menemukan ide-ide terobosan yang berpotensi membawa masyarakat dari ekonomi berbasis kas tunai menuju ekonomi ditigal dan memberikan mereka sarana untuk meningkatkan taraf kehidupan mereka. Malako merupakan perusahaan start up binaan Digital Financial Services (DFS) Lab dan telah mendapatkan pendanaan \$100.000.(TechMoran, 2016).

\section{Kunci Keberhasilan}

Dari ketiga inovasi teknologi finansial yang telah disebutkan pada bagian sebelumnya, maka dapat dianalisis beberapa faktor yang menjadikan mereka dapat meningkatkan inklusi keuangan dan pada akhirnya meningkatkan perekonomian:

1. Memahami karakter penduduk dan ekosistem sistem pembayaran yang sudah terbangun. Sebuah inovasi teknologi keuangan harus melakukan kaijan dan riset untuk mendalami pola kehidupan masyarakat dan perilaku keuangan mereka. Masyarakat dengan pendidikan rendah dan pekerjaan informal akan susah untuk mengakses jasa teknologi finansial yang rumit dan membutuhkan perangkat yang canggih dan mahal. Flutterwave, Creditfix, dan Malako kesemuanya berangkat dari permasalahan lokal yang dihadapi oleh penduduk di negara berkembang. Cara-cara tradisional untuk meningkatkan inklusi keuangan ataupun membawa tekfin dari kota tidak dapat sepenuhnya dapat diaplikasikan pada masyarakat seperti ini.

2. Kemampuan untuk mentransformasi teknologi yang rumit menjadi user interface dan penggunaan yang mudah bagi pengguna. Flutterwave menggunakan teknologi yang canggih untuk bisa mengintegrasikan semua jenis pembayaran sehingga memudahkan bagi pengguna. Creditfix menggunakan algoritma yang akurat untuk bisa menilai skor kredit seseorang sehingga mudah digunakan. Tingkat kemudahan yang dibutuhkan juga lebih tinggi daripada tekfin yang sukses di daerah dan negara maju.

3. Kolaborasi dengan lembaga keuangan formal yang sudah ada. Ketiga contoh praktik terbaik pada penelitian ini tidak memisahkan diri dari industri 
keuangan yang sudah sejak awal bahkan membangun sebuah kolaborasi yang saling menguntungkan semua pihak.

\section{Kesimpulan dan Saran}

Kemajuan teknologi digital telah mempengaruhi industri jasa keuangan dan menciptakan sebuah industri tersendiri yaitu teknologi finansial, yang dapat diartikan sebagai pemanfaatan teknologi (informasi) dalam sektor keuangan dan memberikan fokus lebih pada pengalaman pengguna (user expereience).

Tekfin dengan teknologi canggihnya dibangun dalam ekosistem, infrastruktur, dan budaya masyarakat yang ideal. Tingkat adopsi tekfin sangat tinggi pada daerah/negara yang infrastrukturnya sudah baik (seperti jaringan internet), masyarakat yang sudah familiar dengan gaya hidup digital dan mampu menjangkau device untuk dapat menggunakan produk dan jasa tekfin.

Sementara itu, hal-hal ideal tersebut tidak ditemukan pada daerah/negara berkembang dan tertinggal. Pendapatan masyarakat yang rendah, infrastruktur yang terbatas, pengetahuan masyarakat yang rendah, masyarakat yang masih less digital, dan masyarakat yang tidak teratur secara ekonomi menjadikan tekfin tidak dapat masuk dengan mudah. Dengan karakteristik seperti ini pula membatasi akses mereka terhadap lembaga keuangan formal. Tekfin sebagai sebuah inovasi seharusnya memberikan solusi bagi masyarakat yang terabaikan dalam sistem keuangan formal.

Penelitian ini mencoba mencari praktik terbaik perusahaan tekfin yang secara model bisnis didesain untuk meningkatkan inklusi keuangan masyarakat di daerah/negara tertinggal. Dalam pembahasan penelitian difokuskan pada tiga perusahaan tekfin dari negara yang berbeda dan memberikan solusi yang berbeda juga.

Yang pertama adalah Flutterwave, merupakan platform yang mempersatukan berbagai jenis, metode, dan jaringan sistem pembayaran di negara-negara Afrika serta mengintegrasikannya dengan sistem pembayaran global. Yang kedua, Creditfix, platform yang menghubungkan lembaga keuangan formal dengan masyarakat yang tidak mempunyai rekam jejak finansial dengan membangun sistem penilaian kelayakan kredit (credit scoring) berbasis big data dari perilaku digital mereka sehari-hari. Ketiga adalah Malako, sebuah platform yang memungkinkan masyarakat untuk mendapatkan kredit mikro yang fleksibel dan terjangkau, karena nasabah dapat mengembalikan ketika sudah mempunyai dana yang cukup atau cukup membayar cicilan minimal saat tidak mempunyai dana.

Ketiga perusahan tersebut mempunyai model bisnis yang berbeda, namun memiliki kesamaan yang membuat mereka dapat menjadi solusi bagi peningkatan tingkat inklusi keuangan masyarakat, yaitu: 1) kemampuan untuk memahami kebutuhan masyarakat. 2) kemampuan untuk menyederhanakan kompleksitas teknologi dan model bisnis, 3) kolaborasi dengan lembaga keuangan formal.

Penelitian dapat menjadi pondasi awal bagi penelitian-penelitian selanjutnya yang terkait dengan peran tekfin di negara-negara berkembang. Beberapa perusahaan tekfin yang dibahas dalam penelitian ini merupakan perusahaan yang baru didirikan paling lama 3 tahun terakhir. Konsekuensinya adalah dampak keberadaannya bisa jadi masih sangat kecil jika dibandingkan dengan potensinya. Sehingga sangat disarankan bagi penelitian- penelitian selanjutnya untuk menganalisis pada beberapa tahun ke depan, terlebih dalam banyak kasus perusahaan start up tidak bertahan lama karena model bisnisnya tidak berkelanjutan.

\section{Daftar Pustaka}

Arner, D. W., Barberis, J. N. \& Buckley, R. P., 2015. The Evolution of Fintech: A New Post-Crisis Paradigm?. University of Hong Kong Faculty of Law Research Paper No. 2015/047.

Australian Government, 2017. The Treasury of Australian Government. [Online]

Available at: https://fintech.treasury.gov.au/economicbenefits-of-fintech/

[Accessed 8 June 2017].

Bank Indonesia, 2016. Financial Technology: Analisa Peluang Indonesia dalam Era Ekonomi Digital dari Aspek Infrastruktur, Teknologi, SDM, dan Regulasi Penyelenggara dan Pendukung jasa Sistem Pembayaran, Jakarta: Bank Indonesia.

Bettinger, A. L., 1972. FINTECH - A Series of 40 Time Shared Models Used at Manufacturers Hanover Trust Company'. Interfaces, 2(4), pp. 62-63.

Čižinská, R., Krabec, T. \& Vanegas, P., 2016. FieldsRank: The Network Value of the Firm. International Advances in Economic Research, pp. 1-3.

Fintech Indonesia, 2016. Indonesia Fintech Report 2016, Jakarta: Fintech Indonesia.

Kim, Y., Park, Y. J. \& Choi, J., 2016. The Adoption of Mobile Payment Services for "Fintech". International Journal of Applied Engineering Research, 11(2), pp. 1058-1061.

Micu, I. \& Micu, A., 2016. Financial Technology (Fintech) And Its Implementation on The Romanian Non-Banking Capital Market. SEA-Practical Application of Science, Issue 11, pp. 379-384.

Mishkin, F. S., Matthews, K. \& Giuliodori, M., 2013. The Economics of Money, Banking and Financial Markets. European ed. Edinburgh: Pearson Education.

Otoritas Jasa Keuangan, 2016. Survei Nasional Literasi dan Inklusi Keuangan 2016, Jakarta: OJK.

Romer, P., 1994. The Origin of Endegenous Growth. The Journal of Economic Perspective, 8(1), pp. 3-22.

Schueffel, P., 2016. Taming the Beast: A Scientific of Fintech. Journal of Innovation Management, 4(4), pp. 32-54.

Tapscott, D., 1994. The Digital Economy : Promise and Peril in the Age of Networked Intelligence. 1 ed. s.1.:McGraw-Hill.

Wharton Fintech Club, 2015. Wharton Fintech Club. [Online] Available at: https://medium.com/wharton-fintech/what-isfintech-77d3d5a3e677

[Accessed 19 June 2017].

Crunchbase (2018) Flutterwave. Available at: https://www.crunchbase.com/organization/flutterwave\#secti on-overview. 
Drummer, D. et al. (2016) 'FinTech - Challenges and Opportunities How digitization is transforming the financial sector', McKinsey \& Company.

Flutterwave (2018) About Us. Available at https://www.flutterwave.com/about/ (Accessed: 9 September 2018).

International Telecommunication Union (2018) ICT Facts and Figures. Available at: https://www.itu.int/en/ITUD/Statistics/Documents/facts/ICTFactsFigures2017.pdf.

Kendall, J. (2017) Fintech Companies Could Give Billions of People More Banking Options, Harvard Business Review. Available at: https://hbr.org/2017/01/fintech-companiescould-give-billions-of-people-more-banking-options.

Nicole Jao (2017) Fintech solutions for the world's unbanked. Available at: https://news.itu.int/fintech-solutions-for-theworlds-unbanked/.
Tanmoy Ray (2018) Scopes and Impact of Cloud Computing on Banking \& FinTech. Available at: https://www.stoodnt.com/blog/cloud-computing-bankingfintech/.

TechMoran (2016) Malako, Uganda's microcredit firm raises $\$ 100,000$ from Gates Foundation backed DFS Lab. Available at: https://techmoran.com/malako-ugandas-micro-loansfirm-raises-100000-from-gates-foundation-backed-dfs-lab/.

Triki, T. and Faye, I. (2013) 'Financial inclusion in Africa: an overview', African Development Bank. doi: 10.1596/18139450-6088.

Y Combinator (2016) Flutterwave is Building Digital Payment Infrastructure for Africa. Available at: https://blog.ycombinator.com/flutterwave/. 